\title{
Effects of bamboo salt and its component, hydrogen sulfide, on enhancing immunity
}

\author{
NA-RAE KIM ${ }^{1}$, SUN-YOUNG NAM ${ }^{1}$, KA-JUNG RYU ${ }^{1}$, HYUNG-MIN KIM $^{1}$ and HYUN-JA JEONG ${ }^{2}$ \\ ${ }^{1}$ Department of Pharmacology, College of Korean Medicine, Kyung Hee University, Seoul 130-701; \\ ${ }^{2}$ Department of Food Technology and Biochip Research Center, Hoseo University, \\ Asan, Chungnam 336-795, Republic of Korea
}

Received July 25, 2015; Accepted June 3, 2016

DOI: $10.3892 / \mathrm{mmr} .2016 .5407$

\begin{abstract}
Korean bamboo salt (BS) is known to have therapeutic effects in the treatment of diseases, including viral disease, dental plaque, diabetes, circulatory organ disorders, cancer and inflammatory disorders. However, the effect of BS on immune functions remains to be elucidated. The present study was designed to determine the immune-enhancing effect of BS and its component, hydrogen sulfide, using RAW264.7 macrophages and a forced swimming test (FST) animal model. BS and sodium hydrosulfide (NaSH), a hydrogen sulfide donor, significantly increased the levels of tumor necrosis factor (TNF)- $\alpha$ through the activation of nuclear factor- $\mathrm{KB}$ in the RAW 264.7 cells. In an in vivo experiment, $\mathrm{BS}$ and $\mathrm{NaSH}$ were administered orally once a day for 28 days. After the 28 days, the immobility times in the FST were significantly decreased in the BS and NaSH-fed groups, compared with the control group. In addition, BS and NaSH induced significant increases in the levels of interferon- $\gamma$, interleukin- 2 and TNF- $\alpha$, compared with the control group. Taken together, these results indicated that $\mathrm{BS}$ and $\mathrm{NaSH}$ may improve immune function.
\end{abstract}

\section{Introduction}

The immune response to microbial pathogens relies on innate and adaptive components $(1,2)$. The innate and adaptive immune responses are lowered in diseases associated with

Correspondence to: Professor Hyun-Ja Jeong, Department of Food Technology and Biochip Research Center, Hoseo University, 20 Hoseo-Ro, 79 Beon-Gil, Baebang-Eup, Asan, Chungnam 336-795, Republic of Korea

E-mail: hjjeong@hoseo.edu

Professor Hyung-Min Kim, Department of Pharmacology, College of Korean Medicine, Kyung Hee University, 26 Kyungheedae-Ro, Dongdaemun-Gu, Seoul 130-701, Republic of Korea

E-mail: hmkim@khu.ac.kr

Key words: bamboo salt, hydrogen sulfide, sodium hydrosulfide, tumor necrosis factor- $\alpha$, nuclear factor- $\kappa \mathrm{B}$, macrophages, forced swimming test immunodeficiency $(3,4)$. Deficiency in minerals and vitamins induces the attenuation of immune functions, including phagocytic activity, natural killer cell activity, delayed type hypersensitivity, antigen-specific antibody production and $\mathrm{T}$ cell proliferation (5). Immunomodulatory agents aid in improving the immune response against pathogens by activating immune cells (6). The innate immune response is mediated predominantly by immune cells, including neutrophils and macrophages. Macrophages are cells in the host defense system, which inhibit the invasion of microorganisms and foreign materials through phagocytic activities, and induce additional adaptive immune responses by synthesizing various inflammatory mediators and cytokines, including nitric oxide (NO) and tumor necrosis factor (TNF)- $\alpha(1,6,7)$. NO is synthesized by inducible NO synthase (iNOS) (8). The expression levels of TNF- $\alpha$ and iNOS are increased by the translocation of nuclear factor- $\mathrm{KB}(\mathrm{NF}-\kappa \mathrm{B})$ to the nucleus and

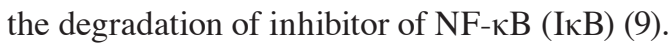

$\mathrm{T}$ cells are also important in immune functions. In particular, helper T cells (Th cells) have two subsets, Th1 and Th2 (10). Th1 cells produce Th1 cytokines, including interferon (IFN)- $\gamma$, interleukin (IL)- 2 and TNF- $\alpha$, which increase cell-mediated immunity. Th2 cytokines released from Th2 cells and promote the humoral antibody-mediated immune response (11). T cell deficiency causes acquired immune deficiency syndrome (12).

Bamboo salt (BS) is a processed salt, produced according to a traditional recipe using sun-dried salt and bamboo in Korea. BS is known to have therapeutic effects in the treatment of diseases, including viral disease, dental plaque, diabetes, circulatory organ disorders, cancer, inflammatory disorders, allergic rhinitis and cisplatin-induced ototoxicity $(13,14)$. Compared with sun-dried salts, BS has a lower toxicity and a higher content of iron, silicon, potassium and phosphate (15-17). In addition, BS contains hydrogen sulfide $\left(\mathrm{H}_{2} \mathrm{~S}\right)$, which is not contained in sun-dried salts. $\mathrm{H}_{2} \mathrm{~S}$ is an endogenous gaseous signaling molecule involved in diverse biological processes, including inflammatory responses, energy metabolism, cell proliferation, apoptosis and oxidative stress (18).

In the present study, the effects of BS and sodium hydrosulfide (NaSH; a $\mathrm{H}_{2} \mathrm{~S}$ donor) on the production of TNF- $\alpha$ and activation of NF- $\mathrm{\kappa B}$ were examined in RAW264.7 cells, a macrophage-like cell line. Furthermore, the 
immune-enhancing effects of $\mathrm{BS}$ and $\mathrm{NaSH}$ were investigated in a forced swimming test (FST) animal model.

\section{Materials and methods}

Cell culture. The RAW264.7 cells were grown in Dulbecco's modified Eagle's medium (DMEM; Gibco; Thermo Fisher Scientific, Inc., Waltham, MA, USA) with $10 \%$ heat inactivated fetal bovine serum (FBS; Gibco; Thermo Fisher Scientific, Inc.,) and $1 \%$ penicillin-streptomycin at $37^{\circ} \mathrm{C}$ in $5 \% \mathrm{CO}_{2}$ and 95\% air. The RAW264.7 cells ( $3 \times 10^{5}$; Korean Cell Line Bank, Seoul, Korea) were treated with BS $(1 \mathrm{mg} / \mathrm{ml}$; Hongik Bio, Damyang, Korea), NaSH (0.01, 0.1 and $1 \mu \mathrm{g} / \mathrm{ml}$; Samchun Pure Chemical Co., Ltd., Pyeongtaek, Korea) or lipopolysaccharide (LPS; $10 \mu \mathrm{g} / \mathrm{ml}$; Sigma-Aldrich, St. Louis, MO, USA) for $24 \mathrm{~h}$ at $37^{\circ} \mathrm{C}$ in $5 \% \mathrm{CO}_{2}$ and $95 \%$ air. The BS and $\mathrm{NaSH}$ were dissolved in distilled water (D.W.). The concentrations of BS $(1 \mathrm{mg} / \mathrm{ml})$ and $\mathrm{NaSH}(0.01,0.1$ and $1 \mu \mathrm{g} / \mathrm{ml})$ were selected in accordance with previous reports $(13,19)$.

Enzyme-linked immunosorbent assay (ELISA). The levels of TNF- $\alpha$ IFN- $\gamma$, and IL-2 cytokines were measured using ELISA, which was performed, as described previously (20). The plates were read at $405 \mathrm{~nm}$ by a microplate reader.

Reverse transcription-polymerase chain reaction (RT-PCR) analysis. Using an Easy-BLUETM RNA extraction kit (iNtRON Biotech, Sungnam, Korea), total RNA was isolated from the RAW264.7 cells, according to the manufacturer's protocol. The concentration of total RNA in the final elutes was determined by NanoDrop (Thermo Scientific, Inc.). Total RNA $(2.5 \mu \mathrm{g})$ was heated at $65^{\circ} \mathrm{C}$ for $10 \mathrm{~min}$ and then chilled on ice. Each sample was reverse-transcribed to cDNA for $90 \mathrm{~min}$ at $37^{\circ} \mathrm{C}$ using a cDNA synthesis kit (Bioneer Corporation, Daejeon, Korea). The polymerase chain reaction (PCR) was performed in a C1000 Touch Thermal Cycler (Bio-Rad Laboratories, Hercules, CA, USA) with the following primers: Mouse TNF- $\alpha$, forward 3'-TAC AGG CTT GTC ACT CGA AT-3' and reverse 5'-ATG AGC ACA GAA AGC ATG AT-3'; actin, forward 5'-GTG GGC CGC TAG GCA CCA-3' and reverse 5'-CGG TTG GCC TTA GGG TTC AGG GGG G-3'. Glyceraldehyde 3-phosphate dehydrogenase (GAPDH) was used to verify whether equal amounts of RNA were used for reverse transcription and amplification from different experimental conditions. PCR was conducted under the following conditions: $94^{\circ} \mathrm{C}$ for $5 \mathrm{~min}, 94^{\circ} \mathrm{C}$ for $45 \mathrm{sec}, 60^{\circ} \mathrm{C}(\mathrm{TNF}-\alpha)$ or $62^{\circ} \mathrm{C}(\mathrm{GAPDH})$ for $45 \mathrm{sec}$ and $72^{\circ} \mathrm{C}$ for $2 \mathrm{~min}$, for 39 cycles; the dinal cycle was followed by an extension for $5 \mathrm{~min}$ at $72^{\circ} \mathrm{C}$. Products were electrophoresed on a $1.5 \%$ agarose gel and visualized by staining with ethidium bromide.

Measurement of nitrite concentration. The RAW264.7 cells were stimulated with BS $(1 \mathrm{mg} / \mathrm{ml}), \mathrm{NaSH}(0.01,0.1$ and $1 \mu \mathrm{g} / \mathrm{ml}$ ) or LPS for $48 \mathrm{~h}$. The concentrations of NO in the cell cultures were measured using a Griess method, as previously described (9).

MTT assay. Cell viabilities were assessed using an MTT assay. Briefly, $500 \mu 1$ of the RAW 264.7 cell $\left(3 \times 10^{5}\right)$ suspension was treated with BS or NaSH for $24 \mathrm{~h}$, followed by treatment with MTT solution $(5 \mathrm{mg} / \mathrm{ml})$ at $37^{\circ} \mathrm{C}$ for $4 \mathrm{~h}$. The insoluble formazan product was dissolved in dimethyl sulfoxide and, the optical density was measured using an ELISA reader at $540 \mathrm{~nm}$.

Western blot analysis. The RAW264.7 cells were stimulated with BS, NaSH or LPS for $1 \mathrm{~h}$. The cell extracts were heated at $95^{\circ} \mathrm{C}$ for $5 \mathrm{~min}$ and briefly cooled on ice. Cell extracts were prepared by a detergent lysis procedure. Cells were scraped, washed once with phosphate-buffered saline (PBS) and resuspended in the radioimmunoprecipitation assay lysis buffer containing $10 \mathrm{mM}$ Tris-HCL pH 7.4, $30 \mathrm{mM} \mathrm{NaCl}, 1 \mathrm{mM}$ EDTA, $1 \%$ Nonidet P-40, supplemented with $1 \mathrm{mM} \mathrm{Na}_{3} \mathrm{VO}_{4}$, $1 \mu \mathrm{g} / \mathrm{ml}$ leupeptin, $1 \mu \mathrm{g} / \mathrm{ml}$ pepstatin A, $1 \mu \mathrm{g} / \mathrm{ml}$ aprotinin and $1 \mathrm{mM}$ PMSF. Samples were vortexed for lysis for a few seconds every $15 \mathrm{~min}$ at $4^{\circ} \mathrm{C}$ for $1 \mathrm{~h}$ and centrifuged at $12,000 \mathrm{x} \mathrm{g}$ for $10 \mathrm{~min}$ at $4^{\circ} \mathrm{C}$. The protein was determined using a bicinchoninic acid assay (Pierce, Rockford, IL, USA) method. Following centrifugation at $12,000 \mathrm{x}$ g at $4^{\circ} \mathrm{C}$ for $10 \mathrm{~min}$, $50 \mu \mathrm{g}$ aliquots were resolved using $12 \%$ SDS-polyacrylamide gel electrophoresis. The resolved proteins were electrotransferred overnight onto nitrocellulose membranes in $25 \mathrm{mM}$ Tris (pH 8.5), $200 \mathrm{mM}$ glycerin and $20 \%$ methanol at $25 \mathrm{~V}$. The blots were blocked for at least $2 \mathrm{~h}$ with $1 \mathrm{X}$ PBS containing $0.05 \%$ Tween 20 with $5 \%$ nonfat dry milk. The blots were then incubated with rabbit polyclonal anti-NF- $\mathrm{KB}$ (sc-7151), mouse monoclonal anti-phosphorylated IkB (pIкB)-a (sc-8404), mouse monoclonal anti-tubulin (sc-8035), mouse monoclonal anti-actin (sc-8432) (Santa Cruz Biotechnology, Inc., Santa Cruz, CA, USA) for $1 \mathrm{~h}$ at room temperature. The blots were developed with monoclonal mouse anti-rabbit peroxidase conjugated-IgG (sc-2357) and monoclonal goat anti-mouse peroxidase- $\operatorname{IgG}$ (sc-2005). for $1 \mathrm{~h}$ at room temperature, and the proteins were visualized using enhanced chemiluminescence procedures, (GE Healthcare, Piscataway, NJ, USA) according to the manufacturer's protocol.

Immunocytochemistry and confocal microscopy. The cells were washed with PBS, fixed with $3.7 \%$ paraformaldehyde for $30 \mathrm{~min}$ and permeabilized with wash buffer $(0.5 \%$ Triton-X in PBS) for $20 \mathrm{~min}$. The cells were then blocked with wash buffer containing $10 \%$ FBS for $1 \mathrm{~h}$, and incubated with anti-NF- $\mathrm{kB}$ (p65) primary antibody for $1 \mathrm{~h}$ at room temperature at 1:500 dilution. Following washing with PBS, the cells were incubated with anti-rabbit fluorescein isothiocyanate-conjugated secondary antibody for $1 \mathrm{~h}$ at room temperature. Following extensive washing with PBS, the slides were scanned under fluorescence with an Olympus confocal microscope (Olympus Corporation, Tokyo, Japan).

Animals. Male ICR mice (10-12 g; 3 weeks old) were obtained from the Dae-Han Experimental Animal Center (Daejon, Korea). Experiments were performed following 1 week of adaptation to the laboratory environment. The animals were housed (five animals per cage) in a laminar air-flow room maintained at a temperature of $22 \pm 1^{\circ} \mathrm{C}$, a relative humidity of $55 \pm 10 \%$ and under a 12:12 light/dark cycle on at $07: 00 \mathrm{~h}$ throughout the experiment. Food and water were available ad libitum. All experiments were performed between 09:00 and 16:00 h, and no animals was used in more than one 

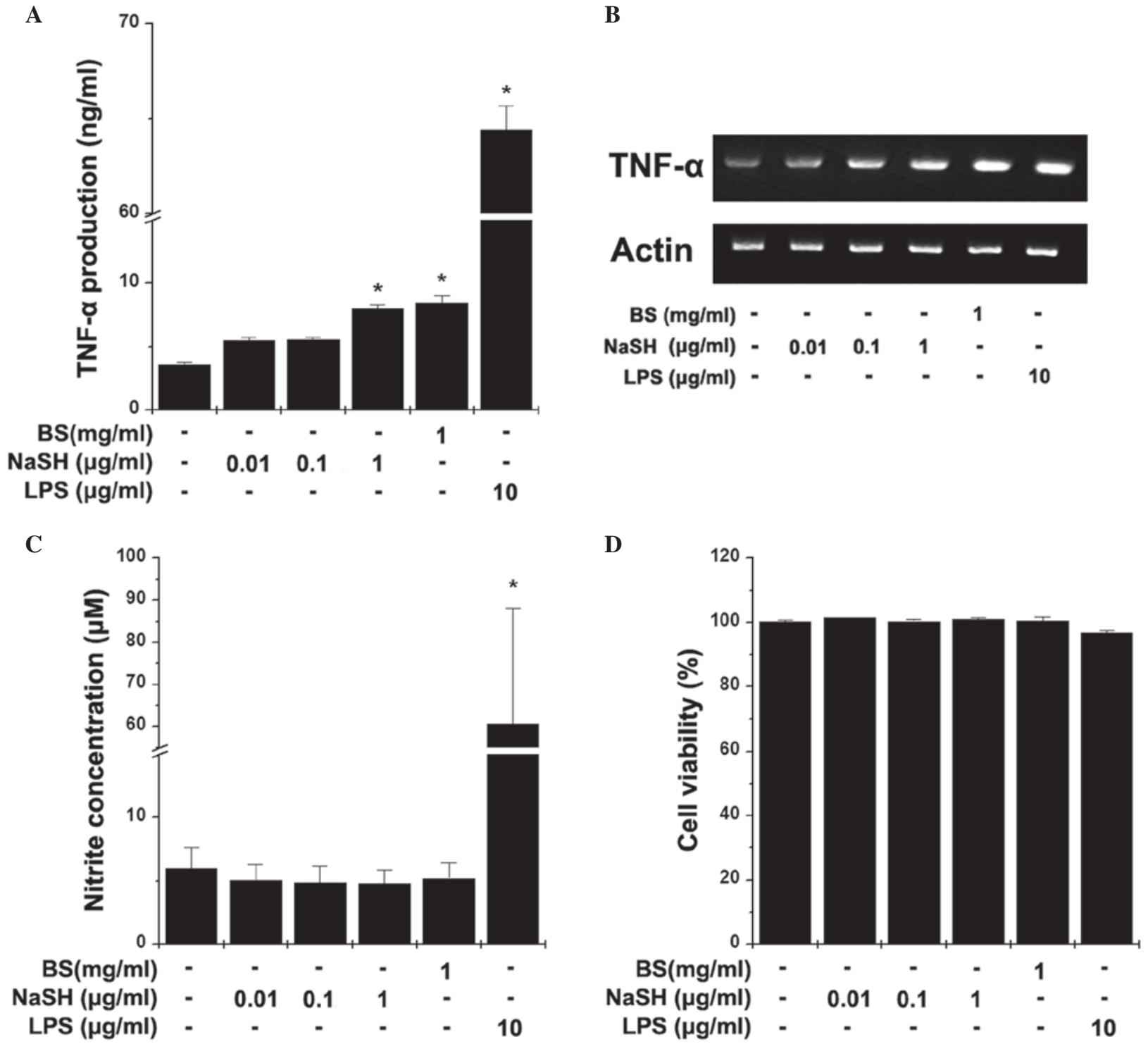

Figure 1. Effect of BS and NaSH on the levels of TNF- $\alpha$ and NO in the RAW264.7 cells. RAW264.7 cells were treated with BS $(1 \mathrm{mg} / \mathrm{ml}), \mathrm{NaSH}(0.01$, 0.1 and $1 \mu \mathrm{g} / \mathrm{ml}$ ) or LPS $(10 \mu \mathrm{g} / \mathrm{ml})$. (A) Production of TNF- $\alpha$ was analyzed using an enzyme-linked immunosorbent assay and (B) mRNA expression of TNF- $\alpha$ was analyzed using reverse transcription-polymerase chain reaction analysis. (C) Production of NO was measured using the Griess method (nitrite). (D) Cytotoxicity was measured using an MTT assay. Data are presented as the mean \pm standard error of the mean of three independent experiments performed in duplicate. "P<0.05, vs. unstimulated cells. BS, bamboo salt; TNF- $\alpha$, tumor necrosis factor- $\alpha$; NO, nitrous oxide.

experiment. All protocols were approved by the Institutional Animal Care and Use Committee of Kyung Hee University [Seoul, Korea; KHUASP (SE)-10-032].

FST. Immobility time was defined as the amount of time that the mouse remained floating in the water without struggling and made only those movements necessary to keep its head above the water. Following the first measurement of immobility times, the mice were divided into a control group, Chlorella vulgaris extract (CVE; $0.3 \mathrm{~g} / \mathrm{kg}$ ) group, BS $(1 \mathrm{~g} / \mathrm{kg})$ group and $\mathrm{NaSH}(0.1$ and $1 \mathrm{mg} / \mathrm{kg})$ groups, based on the recorded swimming times (equivalent average swim time/group). The CVE was supplied by Daesang Corporation (Seoul, Korea), and was dissolved in D.W. as a positive control. BS $(1 \mathrm{~g} / \mathrm{kg}), \mathrm{NaSH}(0.1$ and $1 \mathrm{mg} / \mathrm{kg}), \mathrm{CVE}(0.3 \mathrm{~g} / \mathrm{kg})$ and D.W. were orally administered to the mice in the respective groups once a day for 4 weeks using an atraumatic feeding needle.
The FST was performed on 0 and 28 days after administration of BS or NaSH. The BS, NaSH, CVE and D.W. were administered $1 \mathrm{~h}$ prior to the FST. During the $6 \mathrm{~min}$ of the FST, the immobility time was analyzed, as previously described by Porsolt et al (21). The FST was recorded using a Canon camcorder (Canon, Inc., Tokyo, Japan). The immobility times were measured using a stopwatch by a trained observer, who was blind to the experimental treatments. There were five mice in each group.

Statistical analysis. The results are expressed as the mean \pm standard error of the mean. Statistical significance was compared among each treated group and the control using an independent $t$-test and one-way analysis of variance with Tukey's post-hoc test using SPSS statistical software (SPSS Inc., Chicago, IL, USA). P $<0.05$ was considered to indicate a statistically significant difference. 
A

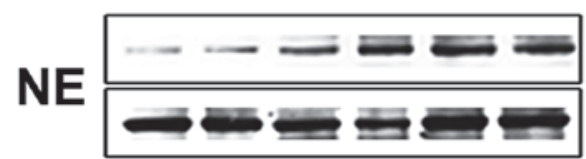

NF-KB

Actin

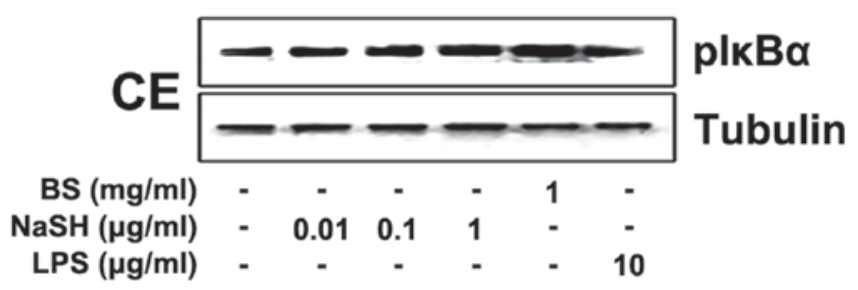

B

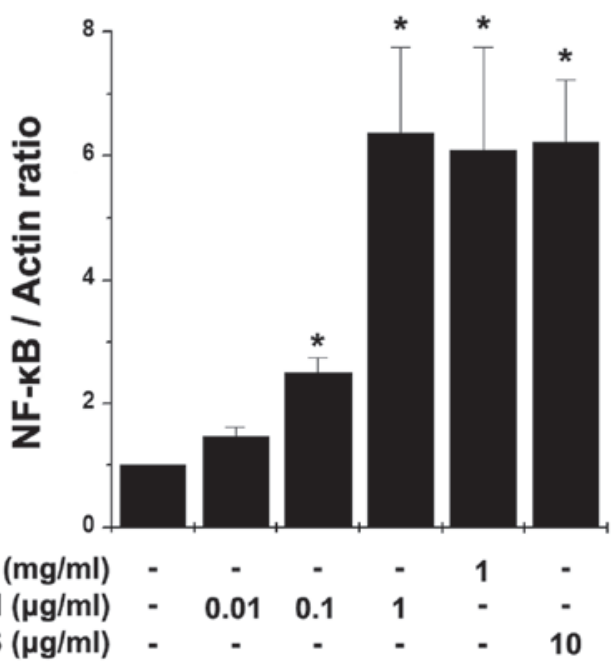

C

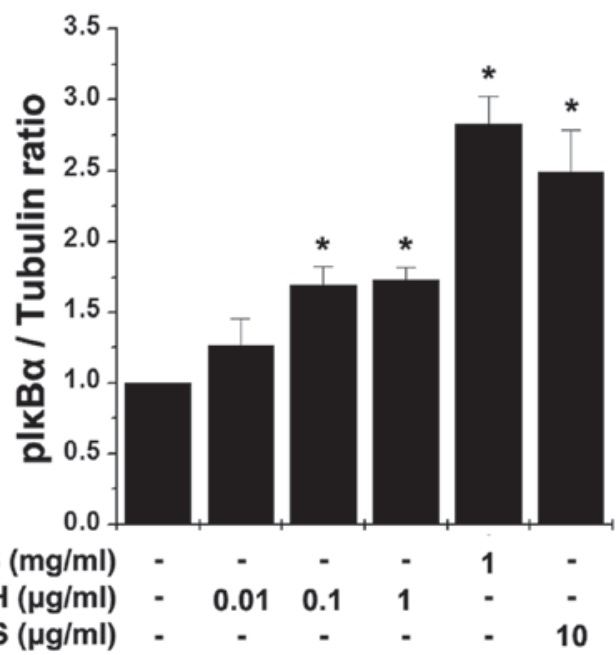

Figure 2. Effect of BS and NaSH on the activation of NF-kB in RAW264.7 cells. RAW264.7 cells were treated with BS $(1 \mathrm{mg} / \mathrm{ml}), \mathrm{NaSH}(0.01,0.1$ and $1 \mu \mathrm{g} / \mathrm{ml}$ ) or LPS (10 $\mu \mathrm{g} / \mathrm{ml})$ for $1 \mathrm{~h}$. (A) Nuclear extracts (NE) were analyzed for NF- $\mathrm{BB}$ and cytoplasmic extracts (CE) were analyzed for $\mathrm{pI \kappa B} \alpha$ using western blot analysis. (B) Relative protein levels of NF- $\mathrm{KB}$ to actin and (C) relative protein levels of $\mathrm{pI} \kappa \mathrm{B} \alpha$ to tubulin were quantified using densitometry. Data are presented as the mean \pm standard error of the mean of three independent experiments performed in duplicate. ${ }^{*} \mathrm{P}<0.05$, vs. unstimulated cells. BS, bamboo salt; LPS, lipopolysaccharide; NaSH, sodium hydrosul-

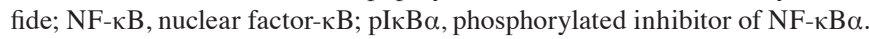

\section{Results}

Effects of BS and NaSH on the production of TNF- $\alpha$ and NO in RAW264.7 cells. Macrophages control the immune system directly through their innate immune functions. Activated macrophages secrete TNF- $\alpha$ and NO. To evaluate the effect of BS and NaSH on the production of TNF- $\alpha$, RAW264.7 cells were treated with BS and $\mathrm{NaSH}$ for $24 \mathrm{~h}$. As shown in Fig. 1A, BS and NaSH $(1 \mu \mathrm{g} / \mathrm{ml})$ significantly increased the production of TNF- $\alpha$, compared with the unstimulated cells $(\mathrm{P}<0.05)$. The mRNA levels of TNF- $\alpha$ were also increased by treatment with BS or NaSH (Fig. 1B). To determine the effects of BS and $\mathrm{NaSH}$ on the production of NO, the RAW264.7 cells were treated with BS and $\mathrm{NaSH}$ for $48 \mathrm{~h}$. BS and $\mathrm{NaSH}$ had no significant effects on the production of NO (Fig. 1C). However, LPS significantly increased the levels of TNF- $\alpha$ and NO (Fig. 1A-C). No cytotoxic effects of BS and $\mathrm{NaSH}$ were observed (Fig. 1D).

Effects of BS and NaSH on the activation of $N F-\kappa B$ in $R A W 264.7$ cells. NF- $\mathrm{kB}$ is a transcription factor, which regulates the expression of TNF- $\alpha$ and is important in immunity (9). Thus, the present study examined the effects of BS and $\mathrm{NaSH}$ on the activation of NF- $\mathrm{kB}$ in the RAW264.7 cells. Stimulation with BS and NaSH induced the translocation of NF- $\mathrm{KB}(\mathrm{p} 65)$ to the nuclei following the phosphorylation of $\mathrm{I} \kappa \mathrm{B} \alpha$ (Fig. 2). Immunocytochemistry for NF- $\mathrm{kB}$ (p65) was also performed; when the RAW 264.7 cells were treated with BS or NaSH, immunoreactive NF- $\kappa \mathrm{B}$ was localized to the nuclei (Fig. 3).

Effects of BS and NaSH on immobility time during the FST. The FST is a behavioral animal model for the evaluation of immune-enhancing drugs (22). The present study investigated the effects of BS and $\mathrm{NaSH}$ on the immobility time during the FST. BS $(1 \mathrm{~g} / \mathrm{kg}), \mathrm{NaSH}(0.1$ and $1 \mathrm{mg} / \mathrm{kg})$ and CVE $(0.3 \mathrm{~g} / \mathrm{kg})$ were orally administered to the mice once a day for 28 days. Measurements of immobility times were performed $1 \mathrm{~h}$ following BS, NaSH and CVE administration. The immobility times were significantly decreased in the BS- and NaSH-administered groups, compared with the control group (Fig. 4; $\mathrm{P}<0.05$ ). CVE also significantly reduced the immobility time (Fig. 4; $\mathrm{P}<0.05$ ).

Effects of BS and NaSH on the levels of Th1 cytokines in the spleen and serum. Th cells are important in the cellular immune response, and are key in host defense systems against bacterial products and viruses (23). The Th1 cytokines secreted by Th1 cells increase cell-mediated immune responses (24), therefore, the present study analyzed the levels of Th1 cytokines (IFN- $\gamma$, IL-2 and TNF- $\alpha$ ) in the spleen and serum following the FST. BS $(1 \mathrm{~g} / \mathrm{kg})$ and $\mathrm{NaSH}(1 \mathrm{mg} / \mathrm{kg})$ significantly increased the levels of IFN- $\gamma$, IL-2 and TNF- $\alpha$ in the spleen (Fig. 5A-C; $\mathrm{P}<0.05$ ). The serum levels of IFN- $\gamma$ were also significantly increased by BS, NaSH and CVE (Fig. 5D; $\mathrm{P}<0.05$ ).

\section{Discussion}

In the present study, it was shown that $\mathrm{BS}$ and $\mathrm{NaSH}$ increased the production of TNF- $\alpha$ and activation of NF- $\kappa B$ in RAW 264.7 cells. BS and NaSH significantly reduced the immobility time in the FST on day 28. In addition, BS and NaSH significantly increased the levels of IFN- $\gamma$, IL-2 and TNF- $\alpha$. 


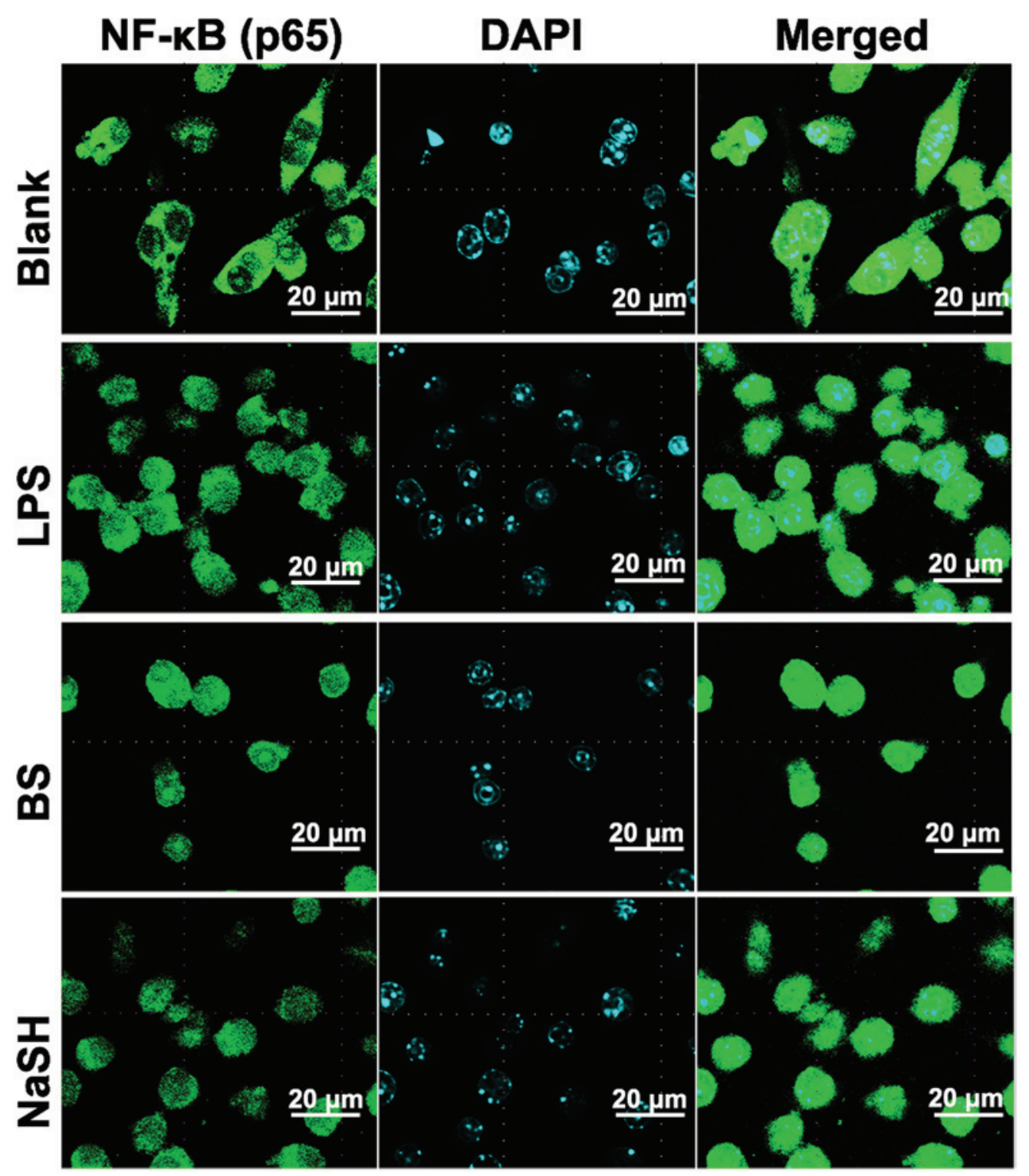

Figure 3. Effect of BS and NaSH on the translocation of NF-kB into the nucleus of RAW264.7 cells. RAW264.7 cells were treated with BS (1 mg/ml), $\mathrm{NaSH}(1 \mu \mathrm{g} / \mathrm{ml})$ or LPS $(10 \mu \mathrm{g} / \mathrm{ml})$ for $1 \mathrm{~h}$. NF- $\mathrm{kB}$ was stained using primary antibody, anti-p65, for $1 \mathrm{~h}$ and then incubated with secondary fluorescein isothiocyanate-conjugated $\mathrm{IgG}$ for $30 \mathrm{~min}$. Results are representative of three independent experiments. (Original magnification, $\mathrm{x} 138$; scale bar=20 $\mu \mathrm{m}$ ).

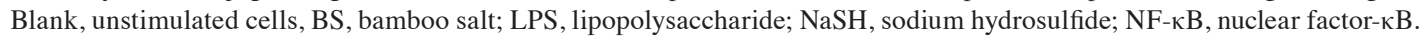

Macrophages are involved in homeostasis, wound repair, tissue remodeling during embryogenesis and the removal of damaged or senescent cells subsequent to injury or infection (7). The activation of macrophages by LPS stimulation increases the production of NO and TNF- $\alpha$ (9). NO is a key molecule for inducing pathogen and tumor cell death, and is synthesized from L-arginine by iNOS (25). The expression of TNF- $\alpha$ is dependent on the activation of the transcription factor, NF- $\kappa B$ (9). NF- $\kappa B$ is a major transcription factor for the expression of innate and adaptive immunity-associated genes (26). In Korea, red ginseng has been known to improve immunity and increase the levels of TNF- $\alpha$ and $\mathrm{NO}$ in RAW264.7 cells (27). In the present study, BS and NaSH increased the levels of TNF- $\alpha$ and activation of NF-kB, suggesting that $\mathrm{BS}$ and NaSH increased the levels of TNF- $\alpha$ via the activation of NF-kB.
Several psychotropic drugs have been developed using the FST $(21,28)$. Although a number of antidepressants reduce immobility time during FSTs (29), the attenuation of lymphocyte proliferation and IL-2 production, damage to natural killer cell cytotoxic responses and reduced neutrophil phagocytosis have been reported following exposure to the FST $(30,31)$. An et al (22) reported that the observed reduction in immobility time by CVE in the FST indicated enhanced immune function and improved physical stamina. Panax ginseng has been used as a traditional Korean medicine for improving physical stamina and enhancing the immune response. The immobility time in the FST has been found to be reduced in mice administered with Panax ginseng (32). In the present study, BS and $\mathrm{NaSH}$ reduced the immobility time during the FST, which indicated that BS and $\mathrm{NaSH}$ had an immune-enhancing effect. 


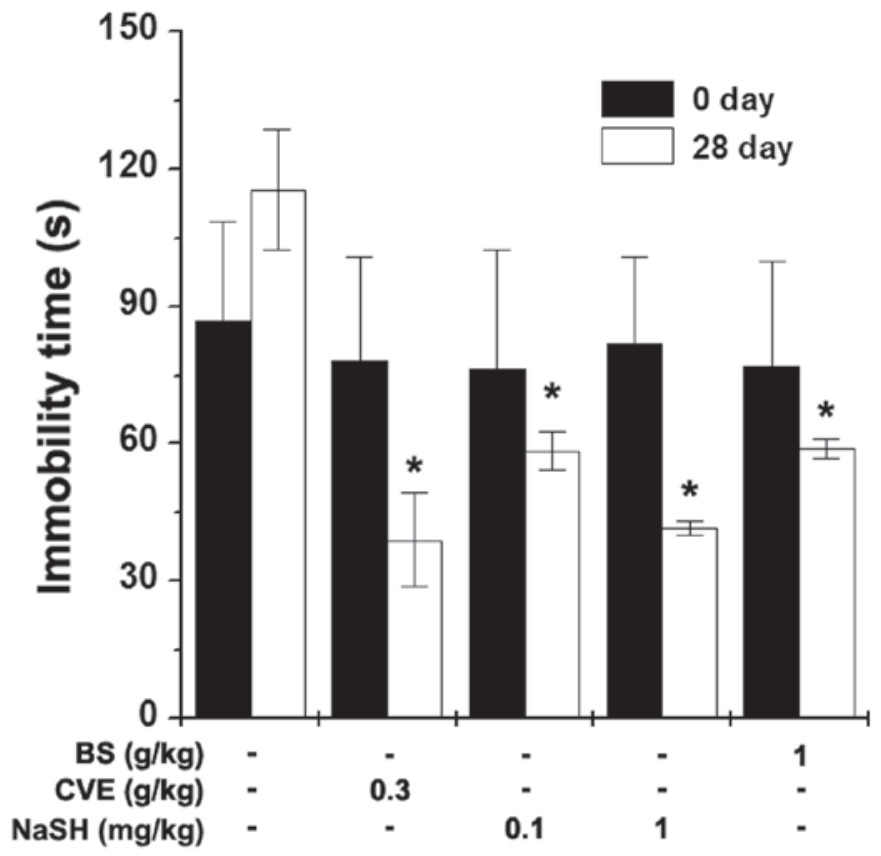

Figure 4. Effect of BS and NaSH on FST-induced immobility in mice. Immobility times during the FST are shown. BS $(1 \mathrm{~g} / \mathrm{kg}), \mathrm{NaSH}(0.01,0.1 \mathrm{and} 1 \mathrm{mg} / \mathrm{kg})$ or CVE $(0.3 \mathrm{~g} / \mathrm{kg})$ were administered $1 \mathrm{~h}$ prior to the FST. Values are presented as the mean \pm standard error of the mean. ${ }^{*} \mathrm{P}<0.05$, vs. distilled water-treated control group. BS, bamboo salt; CVE, Chlorella vulgaris extract; NaSH, sodium hydrosulfide; FST, forced swimming test.

A

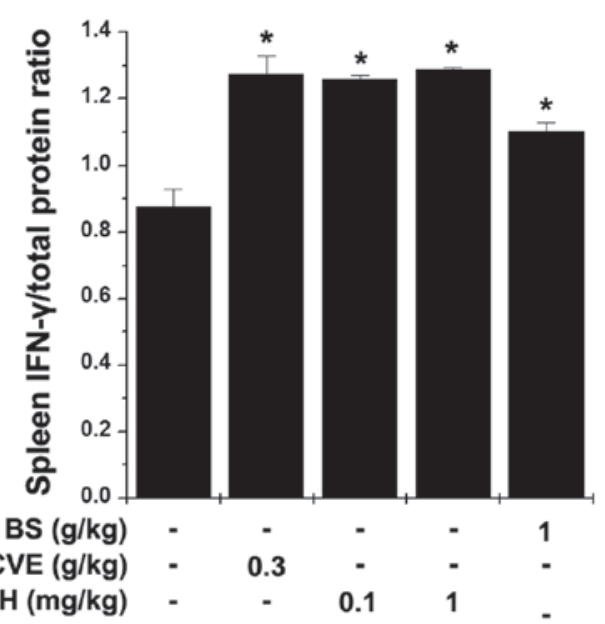

C

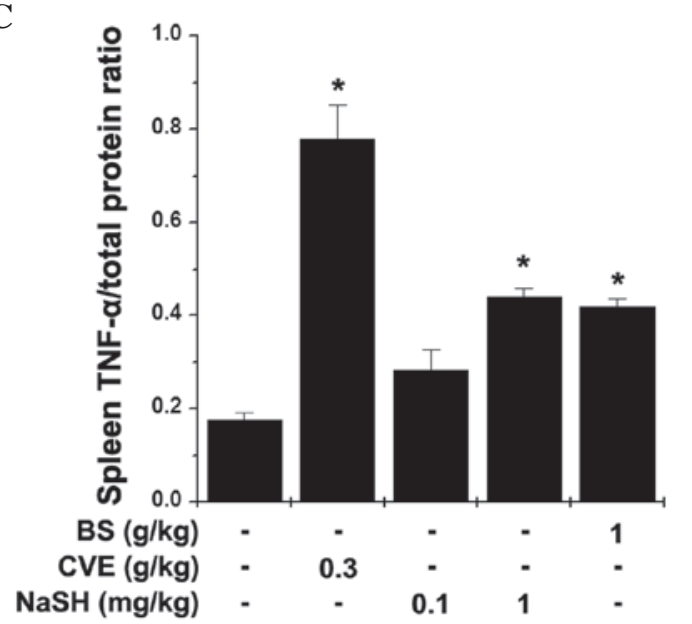

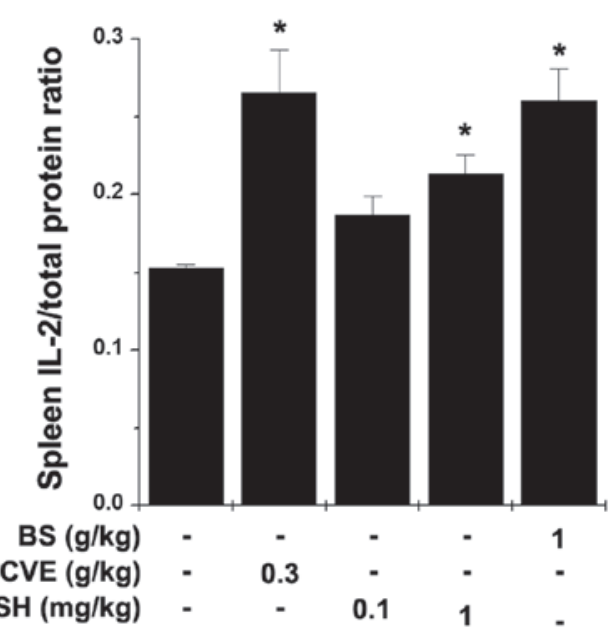

D

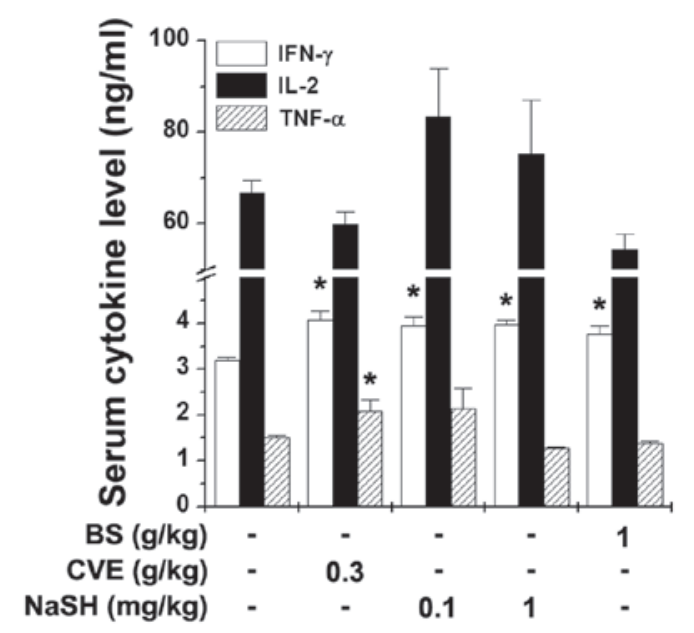

Figure 5. Effects of BS and NaSH on the levels of Th1 cytokines in the spleen and serum. The levels of (A) IFN- $\gamma$, (B) IL-2 and (C) TNF- $\alpha$ in the spleen, and the (D) serum levels of these three cytokines were measured following the FST using an enzyme-linked immunosorbent assay. Values are presented as the mean \pm standard error of the mean. " $\mathrm{P}<0.05$, vs. distilled water-treated control group. BS, bamboo salt; CVE, Chlorella vulgaris extract; NaSH, sodium hydrosulfide; FST, forced swimming test; IFN- $\gamma$, interferon- $\gamma$; IL-2, interleukin-2; TNF- $\alpha$, tumor necrosis factor- $\alpha$. 
The spleen is organized as a tree of branching arterial vessels, and is composed of T cells, B cells, fibroblasts, marginal-zone macrophages and dendritic cells. In particular, Th1 cells are a key factor in the cellular immune response and have a central role in host defense systems against various pathogens (12). Th1 cytokines, including IFN- $\gamma$, IL-2 and TNF- $\alpha$ are produced from Th1 cells and are vital in regulation of the immune response, activating lymphocytes, macrophages and polymorphonuclear cells to destroy bacterial pathogens (24). IFN- $\gamma$ is crucial in immunity against intracellular pathogens and in the control of tumors (33). IL-2 is a cytokine messenger protein, which activates components of the immune system. Several studies have established IL-2 as the lymph cytotropic cytokine, responsible for signaling helper $\mathrm{T}$ lymphocyte $\left(\mathrm{CD} 4^{+}\right.$ T cell) proliferation (34). TNF- $\alpha$ performs important functions in the protection of cells from viral infection or in promoting the selective elimination of virally-infected cells via an IFN-independent mechanism (35). Anticancer drugs induce potent cellular immune responses leading to the production of IFN- $\gamma$, IL-2 and TNF- $\alpha$ (36). CVE, which functions in immune enhancing, increases the levels of IL-2 and IFN- $\gamma$ in $\mathrm{T}$ cells (37). In the present study, it was shown that BS and $\mathrm{NaSH}$ induced a significant increase in Th1 cytokines in the spleen and serum. These results suggested that BS and $\mathrm{NaSH}$ may have useful effects in the treatment of cancer and infections via immune enhancement. However, further investigation is required to clarify the anticancer and antiviral effects of BS and $\mathrm{NaSH}$.

The administration of minerals enhances the host immune response (38). Zinc has been shown to be necessary for physiological functioning of the innate and adaptive immune systems, and it is particularly important for the development of T cells and their peripheral functions following maturation (39). Copper and magnesium are known to be important in the development and maintenance of the immune system $(40,41)$. Iron contributes to the regulation of body temperature following physical exercise and controlling immune defenses (42). $\mathrm{H}_{2} \mathrm{~S}$ involves the cell signaling pathways, which may be involved in cytoprotective, anti-inflammatory and anti-apoptotic actions, and in the modulation of ion channels and metabolism, including the production of mitochondrial ATP $(43,44)$. In the present study, it was shown that bamboo salt and $\mathrm{NaSH}$ had immune-enhancing effects. Bamboo salt contains $\mathrm{H}_{2} \mathrm{~S}$, in addition to 70 essential minerals and micronutrients (17). Therefore, the present study hypothesized that $\mathrm{H}_{2} \mathrm{~S}$ is an active component of BS in immune functions.

In conclusion, the present study showed for the first time, to the best of our knowledge, that $\mathrm{BS}$ and $\mathrm{H}_{2} \mathrm{~S}$ significantly increased the production of TNF- $\alpha$ via the activation of NF- $\kappa \mathrm{B}$ in the RAW264.7 cells. BS and $\mathrm{H}_{2} \mathrm{~S}$ significantly reduced the immobility times in the FST, and significantly increased the levels of IFN- $\gamma$, IL-2 and TNF- $\alpha$. Taken together, these results suggested that $\mathrm{BS}$ and $\mathrm{H}_{2} \mathrm{~S}$ may offer potential as essential agents for the enhancement of immune function.

\section{Acknowledgements}

This study was supported by a grant (grant no. 20130290) to the Solar Salt Research Center from the Ministry of Oceans and Fisheries of Korea.

\section{References}

1. Aderem A and Ulevitch RJ: Toll-like receptors in the induction of the innate immune response. Nature 406: 782-787, 2000.

2. Hoffmann JA, Kafatos FC, Janeway CA and Ezekowitz RA: Phylogenetic perspectives in innate immunity. Science 284: 1313-1318, 1999.

3. Bonilla FA, Bernstein IL, Khan DA, Ballas ZK, Chinen J, Frank MM, Kobrynski LJ, Levinson AI, Mazer B, Nelson RP Jr, et al: Practice parameter for the diagnosis and management of primary immunodeficiency. Ann Allergy Asthma Immunol 94 (5 Suppl 1): S1-S63, 2005.

4. Younger EM, Epland K, Zampelli A and Hintermeyer MK: Primary immunodeficiency diseases: A primer for PCPs. Nurse Pract 40: 1-7, 2015

5. Kaminogawa $S$ and Nanno M: Modulation of immune functions by foods. Evid Based Complement Alternat Med 1: 241-250, 2004.

6. Park HJ, Yang HJ, Kim KH and Kim SH: Aqueous extract of Orostachys japonicus A. Berger exerts immunostimulatory activity in RAW 264.7 macrophages. J Ethnopharmacol 170: 210-217, 2015.

7. Adams OD and Hamilton TA: Molecular basis of macrophage activation and its origins. Oxford University Press, New York, pp75-pp114, 1992.

8. Nathan C: Nitric oxide as a secretory product of mammalian cells. FASEB J 6: 3051-3064, 1992.

9. Jeong HJ, Han NR, Kim KY, Choi IS and Kim HM: Gomisin A decreases the LPS-induced expression of iNOS and COX-2 and activation of RIP2/NF- $\kappa \mathrm{B}$ in mouse peritoneal macrophages. Immunopharmacol Immunotoxicol 36: 195-201, 2014.

10. Del Prete GF, De Carli M, Mastromauro C, Biagiotti R, Macchia D, Falagiani P, Ricci M and Romagnani S: Purified protein derivative of Mycobacterium tuberculosis and excretory-secretory antigen(s) of Toxocara canis expand in vitro human T cells with stable and opposite (type $1 \mathrm{~T}$ helper or type $2 \mathrm{~T}$ helper) profile of cytokine production. J Clin Invest 88: 346-350, 1991.

11. Carter LL and Dutton RW: Type 1 and type 2: A fundamental dichotomy for all T-cell subsets. Curr Opin Immunol 8: 336-342, 1996.

12. Linder $\mathrm{J}$ : The thymus gland in secondary immunodeficiency. Arch Pathol Lab Med 111: 1118-1122, 1987.

13. Kim KY, Nam SY, Shin TY, Park KY, Jeong HJ and Kim HM: Bamboo salt reduces allergic responses by modulating the caspase-1 activation in an OVA-induced allergic rhinitis mouse model. Food Chem Toxicol 50: 3480-3488, 2012.

14. Kim YS, Lee EH and Kim HM: Surprisingly, traditional purple bamboo salt, unlike other salts does not induce hypertension in rats. TANG 3: e16, 2013

15. Nam SY, Oh HA, Choi Y, Park KY, Kim HM and Jeong HJ: Inhibition of IL-32 signaling by bamboo salt decreases pro-inflammatory responses in cellular models of allergic rhinitis. J Med Food 17: 939-948, 2014.

16. Shin HY, Na HJ, Moon PD, Shin T, Shin TY, Kim SH, Hong SH and Kim HM: Inhibition of mast cell dependent immediate-type hypersensitivity reactions by purple bamboo salt. J Ethnopharmacol 91: 153-157, 2004.

17. Zhao X, Kim SY and Park KY: Bamboo salt has in vitro anticancer activity in HCT-116 cells and exerts anti-metastatic effects in vivo. J Med Food 16: 9-19, 2013.

18. Han J, Xuan JL, Hu HR and Chen ZW: Effects and mechanisms of hyperoside on vascular endothelium function in middle cerebral arteries of rats ex vivo. Zhongguo Zhong Yao Za Zhi 39: 4849-4855, 2014 (In Chinese).

19. Zhang Y, Li H, Zhao G, Sun A, Zong NC, Li Z, Zhu H, Zou Y, Yang $X$ and $\mathrm{Ge} J$ : Hydrogen sulfide attenuates the recruitment of $\mathrm{CD} 11 \mathrm{~b}+\mathrm{Gr}-1+$ myeloid cells and regulates Bax/Bcl-2 signaling in myocardial ischemia injury. Sci Rep 4: 4774, 2014.

20. Jeong HJ, Koo HN, Na HJ, Kim MS, Hong SH, Eom JW, Kim KS, Shin TY and Kim HM: Inhibition of TNF-alpha and IL-6 production by Aucubin through blockade of NF-kappaB activation RBL-2H3 mast cells. Cytokine 18: 252-259, 2002.

21. Porsolt RD, Bertin A and Jalfre M: Behavioral despair in mice: A primary screening test for antidepressants. Arch Int Pharmacodyn Ther 229: 327-336, 1977.

22. An HJ, Choi HM, Park HS, Han JG, Lee EH, Park YS, Um JY, Hong SH and Kim HM: Oral administration of hot water extracts of Chlorella vulgaris increases physical stamina in mice. Ann Nutr Metab 50: 380-386, 2006. 
23. Paul WE and Seder RA: Lymphocyte responses and cytokines. Cell 76: 241-251, 1994.

24. Abbas AK, Murphy KM and Sher A: Functional diversity of helper T lymphocytes. Nature 383: 787-793, 1996.

25. Cho CW, Han CJ, Rhee YK, Lee YC, Shin KS, Shin JS, Lee KT and Hong HD: Cheonggukjang polysaccharides enhance immune activities and prevent cyclophosphamide-induced immunosuppression. Int J Biol Macromol 72: 519-525, 2015.

26. Baker RG, Hayden MS and Ghosh S: NF- $\kappa B$, inflammation, and metabolic disease. Cell Metab 13: 11-22, 2011.

27. Park SY, Kim HB, Kim JH, Lee JM, Kim SR, Shin HS and Yi TH: Immunostimulatory effect of fermented red ginseng in the mouse model. Prev Nutr Food Sci 19: 10-18, 2014.

28. Connor TJ, Kelliher P, Shen Y, Harkin A, Kelly JP and Leonard BE: Effect of subchronic antidepressant treatments on behavioral, neurochemical, and endocrine changes in the forced-swim test. Pharmacol Biochem Behav 65: 591-597, 2000.

29. Jeong HJ, Kim JH, Kim NR, Yoou MS, Nam SY, Kim KY, Choi Y, Jang JB, Kang IC, Baek NI and Kim HM: Antidepressant effect of Stillen. Arch Pharm Res 38: 1223-1231, 2015.

30. Irwin M, Smith TL and Gillin JC: Low natural killer cytotoxicity in major depression. Life Sci 41: 2127-2133, 1987.

31. Shu J, Stevenson JR and Zhou X: Modulation of cellular immune responses by cold water swim stress in the rat. Dev Comp Immunol 17: 357-371, 1993.

32. Shin HY, Jeong HJ, Hyo-Jin-An, Hong SH, Um JY, Shin TY, Kwon SJ, Jee SY, Seo BI, Shin SS, et al: The effect of Panax ginseng on forced immobility time \& immune function in mice. Indian J Med Res 124: 199-206, 2006.

33. Yamaguchi R, Kawata J, Yamamoto T, Ishimaru Y, Sakamoto A, Ono T, Narahara S, Sugiuchi H, Hirose E and Yamaguchi Y: Mechanism of interferon-gamma production by monocytes stimulated with myeloperoxidase and neutrophil extracellular traps. Blood Cells Mol Dis 55: 127-133, 2015.

34. Shaker MA and Younes HM: Interleukin-2: Evaluation of routes of administration and current delivery systems in cancer therapy. J Pharm Sci 98: 2268-2298, 2009.
35. Lee JA, Kim YM, Hyun PM, Jeon JW, Park JK, Suh GH, Jung BG and Lee BJ: Honeybee (Apis mellifera) venom reinforces viral clearance during the early stage of infection with porcine reproductive and respiratory syndrome virus through the up-regulation of Th1-specific immune responses. Toxins (Basel) 7: 1837-1853, 2015.

36. Dalgleish AG: Cancer vaccines. Br J Cancer 82: 1619-1624, 2000.

37. An HJ, Rim HK, Jeong HJ, Hong SH, Um JY and Kim HM: Hot water extracts of Chlorella vulgaris improve immune function in protein-deficient weanling mice and immune cells. Immunopharmacol Immunotoxicol 32: 585-592, 2010.

38. Schafer AS, Leal MLR, Molento MB, et al: Immune response of lambs experimentally infected with Haemonchus contortus and parenterally treated with a combination of zinc and copper. Small Ruminant Res 123: 183-188, 2015.

39. Jansen J, Karges W and Rink L: Zinc and diabetes-clinical links and molecular mechanisms. J Nutr Biochem 20: 399-417, 2009.

40. Percival SS: Copper and immunity. Am J Clin Nutr 67 (5 Suppl): 1064S-1068S, 1998.

41. Tam M, Gómez S, González-Gross M and Marcos A: Possible roles of magnesium on the immune system. Eur J Clin Nutr 57: 1193-1197, 2003.

42. Speich M, Pineau A and Ballereau F: Minerals, trace elements and related biological variables in athletes and during physical activity. Clin Chim Acta 312: 1-11, 2001.

43. Azizi F, Seifi B, Kadkhodaee M and Ahghari P: Administration of hydrogen sulfide protects ischemia reperfusion-induced acute kidney injury by reducing the oxidative stress. Ir J Med Sci, 2015 (Epub ahead of print).

44. Hunter JP, Hosgood SA, Patel M, Furness P, Sayers RD and Nicholson ML: Hydrogen sulfide reduces inflammation following abdominal aortic occlusion in rats. Ann Vasc Surg 29: 353-360, 2015. 